\title{
TEREYAĞI OLARAK SATILAN YAĞLARDA BAZI HİLELER VE KALİTE ÖZELLIKLERİNİN TESPİTİ: ERZURUM ÖRNEĞİ
}

\author{
Songül Çakmakç1 ${ }^{*}$, Kübra Çelik ${ }^{2}$, Hatice Ertem ${ }^{2}$, Halenur Çalışkan ${ }^{2}$ \\ ${ }^{1}$ Atatürk Üniversitesi, Ziraat Fakültesi, Gıda Mühendisliği Bölümü, Erzurum, Türkiye \\ ${ }^{2}$ Atatürk Üniversitesi, Fen Bilimleri Enstitüsü, Gıda Mühendislï̆i Anabilim Dalı, Erzurum, Türkiye
}

Geliş / Received: 18.04.2020; Kabul / Accepted: 14.07.2020; Online bask1 / Published online: 08.08.2020

Çakmakçı, S., Çelik, K., Ertem, H., Çalışkan, H. (2020). Tereyağı olarak satılan yağlarda bazı hileler ve kalite özelliklerinin tespiti: Erzurum örneği. GIDA (2020) 45(4) 800-813 doi: 10.15237/gida.GD20053.

Cakemakçı, S., Celik, K., Ertem, H., Calıskean, H. (2020). Determination of some adulterations and quality properties of fats sold as butter: Er:urum example. GIDA (2020) 45(4) 800-813 doi: 10.15237/gida.GD20053.

\section{ÖZ}

Bu araştırmada, Erzurum'da ulusal büyük firma tereyağlanı hariç, tereyağı olarak satılan yağlant, bazı hileler ve kalite özellikleri bakımından inceleyerek, tüketici şüphelerine ve konunun önemine dikkat çekmek istenmiştir. Bu amaçla, 2020 Şubat-Mart ayları içinde 34 adet yağ incelenmiştir. Örneklerin yağ oranları \%72.5 ile \%86 arasında değişmiş ve sadece 16 adedi tam yağlı tereyağı tipine girmiştir. Reichert Meissl sayılanı 4.35 ile 47.30 olarak geniş bir aralıkta değişmiş, çoğunun başka yağlarla/katkılarla karıştırldığı anlaşılmıştr. Örneklerin kurumadde miktarları \%75.92-90.86, yağsız kurumadde oranları mevzuatın üzerinde bulunmuş, kilogram fiyatları 25-49.5 TL arasında değişmiştir. En düşük ve en yüksek maya ve küf ile koliform bakteri sayıları sırasıyla 5.60-8.04 ve <1-5.09 log KOB/g olarak saptanmış, mevzuatta bilgi bulunmadı̆̆1 ancak sağlık ve kalite açısından bu değerlerin kabul edilemez olduğu görülmüştür. Çok sayıda yağın rengi, kontrolsüz katkıların katılmış olabileceğini göstermiştir. Bu araştırma sonuçları, mevzuatta kanş̧ıklığa neden olan hususlar ve açık bırakılmış eksikliklerin acilen giderilmesi gerektiğini ortaya koymuştur.

Anahtar kelimeler: Tereyağı, Hile, Tüketici, Analiz, Gıda kontrolü, Erzurum

\section{DETERMINATION OF SOME ADULTERATIONS AND QUALITY PROPERTIES OF FATS SOLD AS BUTTER: ERZURUM EXAMPLE}

\begin{abstract}
In this study, it was aimed to draw attention to consumer doubts and the importance of the subject by determining the fats sold as butter in Erzurum, excluding the national big firm butter, in terms of some adulterations and quality properties. For this purpose, 34 fats were investigated in FebruaryMarch 2020. Fat ratios of the samples varied between $72.5 \%$ and $86 \%$, and only 16 of them were in the form of full-fat butter. Reichert Meissl numbers ranged from 4.35 to 47.30 in a wide range, and it was understood that most of them were mixed with other fats/additives. The dry matter amounts of the samples were found to be $75.92-90.86 \%$, and the fat-free total solids rates were higher than the legislation, the kilogram prices varied between 25-49.5 Turkish lira. The lowest and highest yeast
\end{abstract}

${ }^{*}$ Yazışmalardan sorumlu yazar / Corresponding author

$\triangle$ : cakmakci@atauni.edu.tr;

(ग): (+90) 4422312491

圆: (+90) 4422317858

Songül Çakmakçı; ORCID no: 0000-0003-0334-5621

Kübra Çelik; ORCID no: 0000-0003-4828-3671

Hatice Ertem; ORCID no: 0000-0002-0365-9535

Halenur Çalışkan; ORCID no: 0000-0002-9952-8133 
and mold and coliform bacteria numbers were determined as 5.60-8.04 and $<1-5.09 \log \mathrm{cfu} / \mathrm{g}$, respectively, and there was no information in the butter legislation, but these values were unacceptable in terms of health and quality. The color of a large number of fats showed that uncontrolled additives were added. The results of the research showed that the subject matter that cause confusion in the butter legislation and the deficiencies that were left open should be eliminated urgently.

Keywords: Butter, Adulteration, Consumer, Analysis, Food control, Erzurum

\section{GİRIŞ̧}

Tereyağ1, alternatifi olmayan kendine özgü hoş bir lezzete sahip olmasının yanı sira, vücut sıcaklığında eriyebilen, kolay sindirilebilen ve önemli bir enerji kaynağı olması nedeniyle insan beslenmesinde oldukça önemli yere sahip bir süt ürünüdür. Tereyağ1 A vitamini ve/veya $\beta$-karoten ve esansiyel yağ asitlerince de zengin bir yağ çeșididir. Süt yağının konjuge linoleik asit bakımından zengin olması tereyağının önemini artırmaktadır. Ancak, hakkı olarak, diğer yağlara göre ekonomik değerinin yüksek oluşu nedeniyle; kötü niyetli/haksız kazanç sağlamak isteyen kesimler tarafindan her firsatta yapilan hile ve tağşişlerden dolayı (daha çok margarin ilavesi), tüketici yıllardır mağdur olmuș ve aldatılmıștır. Ülkemizde bu konu her zaman güncelliğini sürdürmesine rağmen, özellikle son y1llarda tüketicilerde bu kaygıların arttığ1 görülmektedir. $\mathrm{Bu}$ firsatçllık ve kötü niyete, yağın fiziksel durumunun tağşişe açık olması da kolaylık sağlamaktadır. Dolayısıyla üstün besin değeri, kahvaltı ve bazı yemeklerin vazgeçilmez lezzeti olan ve diğer yağlara göre pahalı olan tereyağından hakkıyla yararlanilamamaktadır.

Konuyla ilgili olarak; Erzurum Ticaret Borsas1 tarafindan da; ilgili kurumlarca yapılan çok sayıdaki denetime rağmen vatandaşın sağlığını hiçe sayan ve saf süt yağ1 ile tereyağ1 üreten üreticilerin rekabet şansını azaltan bazı çevreler tarafından, tereyağına hile yapıldığı ve içeriğinde değişiklik yapılarak satıldığı belirtilmiştir. Bu ürünlere karşı, süt sanayicilerinin talepleri doğrultusunda ilgili resmî kurumlara girișimlerde bulunacakları bildirilmiş ve "tüketicilerin de aldıkları tereyağlarının etiketlerini dikkatle okumaları tavsiye edilmiş, etiketli ürünlerin üzerinde ne kadar bitkisel, ne kadar sütyağ 1 içerdiği mutlaka yazılmalıdır" denilmiştir (Anonymous, 2019). Halbuki sorunun asıl kaynağ1 da budur. Tereyağı olarak satılan yağların büyük çoğunluğu açık yığın olarak satılmakta, üzerlerinde etiket bulunmamaktadır. Uygun olmayan ambalaj malzemelerine sarılan yağlara yapıştırılan etiketlerde de bilgiler eksik olmaktadır.

Tağşişin tespit edilmesinde tereyağını diğer yağlardan ayıran bazı fiziksel ve kimyasal özelliklerin farklıllğı ile kalitatif sonuçlar elde edilmeye çalışılmaktadır. Bunlardan en yaygın kullanılanı Reichert-Meissl (R.M.) sayısını belirlemektir. R.M. sayısı bütirik asit (C4:0) ve kaproik asit (C6:0) gibi sadece süt yağında bulunan kisa zincirli yăg asitlerini tespit etme esasina dayanmaktadır (Metin ve Öztürk, 2002; Pradhan, 2016). Tereyağı hilelerini belirlemede R.M. sayısı, günümüzde halen geçerliliği olan, hızlı ve ucuz bir yöntemdir (Altun vd., 2017). Katk1 oran1 fazlalaştıkça güvenilirliği artmaktadır (Pradhan, 2016; Tahmas Kahyaoğlu ve Çakmakç1, 2016). Daha ileri yöntemlerle de (ATR-MIR) tereyağ1 hileleri belirlenmektedir (Koca vd., 2010). Triaçilgliserol (TAG) profillerini belirleyerek tağşiş belirleme yöntemi de yağların bileşenlerine ayrılmasını ve yüksek performanslı sıv1 kromatografisinde bu bileşenlerin analiz edilmesini içermektedir. Bu teknik hem oldukça uzun sürede sonuç vermekte hem de sadece yağın çok az bileşeni analiz edilebilmektedir. Yine, Diferansiyel Taramalı Kalorimetre (DSC), k1sa sürede sonuç vermesi ve kantitatif veriler elde edilebilmesi bakımından önemli avantajlar sağlamakta (Lambelet ve Ganguli, 1983; Tan ve Man, 2000; Marikkar vd., 2002), ancak tüketicinin endişelerini gidermek için kısa sürede sonuç veren, ucuz ve pratik analizler de önemini korumaktadır. Bu konuda yağ sabitlerinden ve özellikle R.M. sayısından faydalanılarak çıkarılan formül işe yaramaktadır (Tahmas Kahyaoğlu ve Çakmakçı, 2018). Tereyağında tağşşşin kaynağ1 genellikle ucuz yemeklik margarinlerdir. Margarinler, daha fazla trans yağ asidi içermektedir (margarin \%10-35; tereyağ1 \%3-8) (Dıraman, 
2006). Trans yağ asitleri doğada bulunmayıp, daha çok bitkisel kaynaklı yağların 1sıtılması, hidrojenasyonu ve işlenmesi sırasinda oluşmaktadır. Trans yağ asitleri, ruminal aktiviteden dolayı süt kaynaklı yağlarda az miktarda ve çoğunlukla hidrojenasyonla oluşmaktadır. Trans yağ asitlerinin bütün özellikleri cis formundan farklı olup özellikle erime özellikleri cis formunda yaklaşı $13-14{ }^{\circ} \mathrm{C}$, trans formunda 44-45 ${ }^{\circ} \mathrm{C}$ 'dir (Tekin, 2007). Bu bileşikler, düşük yoğunluklu lipoprotein (LDL kolesterol, kötü kolesterol) miktarını artırırken, yüksek yoğunluklu lipoprotein (HDL kolesterol, iyi kolesterol) miktarını düşürmekte ve kalp hastalıkları riskini artırmaktadır (Taşan ve Dağlıŏglu, 2005; Bhardwaj vd., 2011; Çakmakçı ve Tahmas Kahyaoğlu, 2012). Bu nedenle, yüksek miktarda trans yağ asidi tüketimi insan sağllğııı olumsuz etkilediğinden tereyağına margarin katılması ile sadece tüketicinin maddi olarak aldatılması değil, sağlığı da tehlikeye atılmaktadır. Tereyağlarında \%10'un üzerinde trans yağ asidi belirlenmesinin margarin ile yapılmış bir tağşişin göstergesi olarak kabul edilebileceği belirtilmiştir (Diraman, 2006). Bu durum tüketicilerin aldatilmasına neden olmakta ve tüketici fazla para harcadığ1 halde yeterince beslenemediği gibi şüphe durumunda çoğu zaman çaresiz kalmaktadır.

Tereyağına hile yapılması yaygın bir uygulama olup, tüketicileri endişelendirmektedir. $\mathrm{Bu}$ nedenle orijinalliği garantili ürünlere olan talep gittikçe artmaktadır (Karoui ve De Baerdemaeker, 2007). Tereyağına yapılan hilelerin kontrolüne duyulan ihtiyacın artmasına rağmen, spesifik cihaz ve analiz yöntemleri nedeniyle daha çok araşurmalarda kullanılan teknikler yerine; bu araştırmada, bazı basit belirleyicilerle toplumu rahatlatmak ve Erzurum özelinde, tereyağ1 olarak satılan yağların mevcut durumunu belirlemek, yine büyük bir problem olan ve kaynağ1 bilinmeyen boyalarla tereyağını sarıya boyama alışkanlığını göstermek, hiç gerek olmayan bu uygulamanın 2 aylık kış periyodunda bile ne kadar büyük varyasyon gösterdiğini sergilemek amaçlanmıştrr. Tüketicilere saf ve sağlıklı tereyağı sunmak önemli bir sorumluluk olup bu konuda ambalaj, etiketleme ve etiket bilgilerinin güvenilirliği büyük önem taşımaktadır. $\mathrm{Bu}$ araştırma; tüketicinin sağlığını korumaya yönelik olarak maddi ve manevi açıdan aldatılmasını önlemeye ve haksız rekabet ortamında işini düzgün yapan tereyağı üreticisini korumaya katkıda bulunabilmek için yapılmışır. Bu nedenle, Ulusal büyük firma tereyağları hariç, Erzurum İli özelinde yerel üretici firma, market ve satış noktalarından 14 adedi ambalajlı, 20 adedi de açık olarak ve sadece "tereyağı" olarak satışa sunulan yağların TS 1331 (Anonymous, 2015) ve “Türk Gıda Kodeksi Tereyağı, Diğer Süt Yağ1 Esaslı Sürülebilir Ürünler ve Sadeyağ Tebliği-Tebliğ No: 2005/19 (Anonymous, 2005) ve genel baz1 kriterlere uygunluğu araştırlmıştır. Böylece, tereyağı olarak satışa sunulan yağların mevcut durumunu ve bazı hileleri ortaya koyarak, hem tüketicileri bilgilendirmek hem de sonuçlara göre ilgili makamların dikkatini çekerek önerilerde bulunmak amaçlanmışır.

\section{MATERYAL ve YÖNTEM Materyal}

Bu araştırmada, 2020 Yılı Şubat ve Mart ayları içinde Erzurum İli merkezinde farklı üretici firma/market/satış yerlerinde "tereyağı" olarak satışa sunulan yağlardan toplam 34 adet örnek alınmıştır. Haftalık arayla 4 grup halinde $(9+9+8+8$ adetlik gruplar) 14 adedi ambalajl 1 (500 gramlık) ve 20 adedi de açık yığın olarak pazarlanan yağlardan (300-400 g) satın alınmıştır. Alınan örneklerden öncelikle mikrobiyolojik analizler için yağı temsil edecek şekilde, steril cam kavanozlara konulmuştur (örnek alımında satıcıların daha az miktarda yağ alımında, kontrol edilme şüphesi nedeniyle satış yapmak istememelerinden dolayı, tüketici gibi almak zorunda kalınmıştur). Örnekler soğuk şartlarda laboratuvara getirilmiş ve analizler süresince $4 \pm 1^{\circ} \mathrm{C}$ 'de muhafaza edilmiştir.

\section{Yöntem}

Alınan yağ örneklerinde, önce mikrobiyolojik analizler [koliform bakteri ile maya ve küf], sonra diğer analizler [peroksit sayısı, R.M. sayıs1, kurumadde, yağ, yağsız kurumadde, renk analizleri (hem analitik hem de duyusal olarak)] yapılmıştır. Tereyağ1 olarak satışa sunulan yağların satış fiyatı da verilmiştir. 


\section{Mikrobiyolojik analizler}

10 g tereyağ1 örneği, içerisinde $90 \mathrm{~mL}$ steril fizyolojik çözelti (\%0.85 NaCl) bulunan steril cam kavanozlara aseptik koşullarda tartılarak 5 dakika homojenize edilmiştir. Böylece ilk dilüsyon $\left(10^{-1}\right)$ hazırlanmıştır. $\mathrm{Bu}$ dilüsyondan $1 \mathrm{~mL}$ alınarak içerisinde $9 \mathrm{~mL}$ steril dilüsyon sivisı bulunan tüplere aktarılmıştur. $\mathrm{Bu}$ şekilde desimal seyreltmelerle dilüsyonlar hazırlanmıstır. Daha sonra uygun dilüsyonlardan metotlarda verilen normlara uygun olarak petri kutularına ekim yapılmıştrr. Sayım sonuçları dilüsyon faktörü göz önünde bulundurularak değerlendirilmiştir. Metot detayları aşağıda verilmiştir.

\section{Koliform grubu bakteri sayımı}

Violet Red Bile agar (VRBA) (Merck) kaynatulip $45^{\circ} \mathrm{C}$ 'a soğutulduktan sonra, uygun dilüsyonlardan çift petri plağına 1'er $\mathrm{mL}$ ilave edilmiş, soğutulmuş agardan 13-15 mL dökülmüş ve homojen olarak karışması sağlanmıştır. Katulaştıktan sonra tekrar üzerine agardan $10 \mathrm{~mL}$ kadar dökülerek katılaşması beklenmiştir. Katılaşan petriler ters çevrilerek $35-37^{\circ} \mathrm{C}$ 'de 48 saat kadar inkübasyona bırakılmıştır. İnkübasyon sonrası oluşan çapi $0.5 \mathrm{~mm}$ 'den daha büyük olan pembe/ kırmızı koloniler sayılmıştır (Harrigan, 1998).

\section{Maya ve küf sayımı}

Potato Dextrose agar (PDA) (Merck) ile hazırlanan besiyeri sterilize edildikten sonra, $\% 10$ 'luk steril tartarik asit çözeltisi kullanılarak asitlendirilmiş $(\mathrm{pH} 3.5 \pm 0.1)$ ve petrilere $15 \mathrm{~mL}$ kadar dökülmüştür. Besiyeri katılaştıktan sonra uygun dilüsyonlardan ekim yapilarak oda sicaklığında $\quad\left(20-25{ }^{\circ} \mathrm{C}\right) \quad 5-7$ gün süre ile inkübasyona bırakılmıştır. İnkübasyondan sonra oluşan koloniler sayılmıştır (Harrigan, 1998).

\section{Fiziksel ve kimyasal analizler}

Yağ örneklerinde; kurumadde miktan gravimetrik yöntemle, yağ miktarı Gerber yöntemiyle Kurt vd. (2012)'de verilen yöntemlere göre yapılmıştır. Yağsız kurumadde oranı hesapla bulunmuştur. Peroksit say1s1 Atamer (1993) ile Öztürk ve Çakmakçı (2006)'nın verdikleri yönteme göre, R.M. sayıs1 Atamer (1993) ile Metin ve Öztürk (2002) tarafindan verilen yöntemle, renk analizleri ve duyusal analizler de aşağıda ayrıntıları verilen yöntemlerle yapılmıştır.

\section{Renk analizleri}

Tereyağı örneklerinin renk değerleri $\left(L^{*}, a^{*}, b^{*}\right.$ ve $H^{\circ}$ ve $C^{*}$ değerleri) Minolta Colorimeter CR-200 (Minolta Camera Co., Osaka, Japan) ile Konica Minolta (2007)'da belirtildiği gibi ölçülmüştür. CIE $L^{*}, a^{*}, b^{*}$ renk değerleri olarak: $L^{*}$ parlaklığ1 göstermekte olup $L=0$ siyah ve $L=100$ beyaza karşılık gelmektedir. + $a$ değeri kırmızıllı̆̆, $-a$ değeri yeşilliği, $+b$ değeri sarllığ ve $-b$ değeri de maviliği göstermektedir (Savaş Bahçeci ve Acar, 2020). C* değeri; renk (Chroma) değeri olup, silindirin merkezinden dişa doğru artan değeri $(0 \ldots 60)$ gösterir. $H^{\circ}$ değeri (açı) ise renk canlllığını ifade eder ve birimi derece $\left(^{\circ}\right)$ olup $+a^{*}$ ile başlar. Açı ve renk ilişkisi şöyledir: $0^{\circ}:+a^{*}(\mathrm{k} ı r m ı z 1), 90^{\circ}$ : $+b^{*}$ (sar1), 180 : - - ${ }^{*}$ (yeşil), 270 $:-b^{*}$ (mavi) (Konica Minolta, 2007; Keskin vd., 2017). Örneklerde ölçümler, üç farklı noktadan okunan renk değerlerinin ortalaması alınarak hesaplanmıştır. Ölçümler yapılmadan önce cihaz beyaz kalibrasyon plakası ile kalibre edilmiş ve bütün ölçümler beyaz bir zemin üzerinde düzgün yüzeyli kaplara yerleştirilen örnekler kullanılarak gerçekleştirilmiştir.

\section{Duyusal analizler}

Yağ örneklerinde renk ve görünüş, tat ve koku özellikleri Tereyağ1 Standardı - TS 1331 (Anonymous, 2015) ve Türk Gıda Kodeksi Tereyağı, Diğer Süt Yağı Esaslı Sürülebilir Ürünler ve Sadeyağ Tebliği -Tebliğ No: 2005/19 (Anonymous, 2005)'da belirtilen 'Ürünler, kendine has tat, koku, görünüm ve yapıda olmalı, yabanc1 tat ve koku ihtiva etmemelidir" şeklindeki açıklamalara göre, tereyağını seven, deneyimli 8 kişilik panelist grubu tarafindan değerlendirilmiştir. $\mathrm{Bu}$ kriterler açısından değerlendirme için; örnek alımında da belirtildiği gibi, partiler halinde alınan tereyağı örnekleri Şekil 1'de görüldügü gibi plastik küçük kaplara her panelist için 2'şer adet aynı miktar ve özenle yerleştirilip ağızları kapatılıp buzdolabına konulmuştur (1 adedi, tüm örnek alımları tamamlandığında renk ve görünüş açısından toplu değerlendirme yapmak için buzdolabinda muhafaza edilmiştir). Daha sonra, örneklerden 1'er adedi buzdolabından çıkarılmış ve 1 dakika 
sonra (donuk rengin yanılmaya neden olmamas1 için), karşılaştırma amacıyla partide toplu olarak renk, görünüm ve koku değerlendirmesi yapılmış, daha sonra plastik çay kaşıklarıyla karıştırılarak tekstür ve daha sonra da aynı kaşıkla lezzet ile yabanc1 tat açısından tecrübeye dayalı değerlendirilmiştir. Tüm örnek alımı tamamlandığında da tüm örneklerin renk ve görünüş değerlendirmesi kontrol edilmiştir. Örnekler arasinda panelistlere sade ekmek ve $11 \mathrm{kk}$ su verilmiştir. Duyusal analiz oda sıcaklığında ve floresan lamba altında yapılmıstur.

\section{SONUÇ ve TARTIŞMA}

Toplam 34 adet tereyağ1 örneğinin bazı mikrobiyolojik analiz sonuçları ve yağların belirli kriterlere göre yapılıp yapılmadığını belirlemek, tüketicilerin merak ettikleri/şüphe duyduklanı ve tereyağlarına güvenlerini sarsan düşüncelerine $1 s ̧ 1 \mathrm{k}$ tutmak amaciyla yapılan bazı kimyasal analiz sonuçları Çizelge 1'de toplu olarak verilmiştir.

Çizelge 1. Tereyağı olarak satılan yağların kimyasal, mikrobiyolojik özellikleri ve fiyatlanı Table 1. Chemical, microbiological properties and prices of fats sold as butter

\begin{tabular}{|c|c|c|c|c|c|c|c|c|}
\hline $\begin{array}{c}\text { Örnekler } \\
\text { Samples }\end{array}$ & $\begin{array}{c}\mathrm{KM}^{1} \\
(\%) \\
D M^{1 a} \\
(\%)\end{array}$ & $\begin{array}{l}\text { Yă̆ } \\
(\%) \\
F a t \\
(\%)\end{array}$ & $\begin{array}{c}\text { Yağsiz } \\
\mathrm{KM}(\%) \\
\text { Non-fat } \\
D M(\%)\end{array}$ & $\begin{array}{c}\text { Peroksit } \\
\text { Say1s1 (meq } \\
\left.\mathrm{O}_{2} / \mathrm{kg}\right) \\
\text { Peroxide value } \\
\left.\text { (meq } \mathrm{O}^{2} / \mathrm{kg}\right)\end{array}$ & $\begin{array}{c}\text { R.M. } \\
\text { Say1si }^{2} \\
\text { R.M. } \\
\text { Number }^{2 a}\end{array}$ & $\begin{array}{c}\text { Maya ve küf } \\
\text { say1s1 } \\
\text { (log } \mathrm{KOB} / \mathrm{g}) \\
\text { Yeast and mold } \\
\text { count }(\log c f u / g)\end{array}$ & $\begin{array}{l}\text { Koliform } \\
\text { bakteri (log } \\
\mathrm{KOB} / \mathrm{g}) \\
\text { Coliform } \\
\text { bacteria count } \\
(\log c \mathrm{fu} / \mathrm{g})\end{array}$ & $\begin{array}{c}\text { Fiyat1 } \\
\text { (kg) } \\
\text { (TL) } \\
\text { (Price) (kg) } \\
\text { (Turkish } \\
\text { lira) }\end{array}$ \\
\hline 1 & 86.68 & 81.2 & 5.48 & 1.05 & 4.35 & 6.67 & 4.31 & 38 \\
\hline 2 & 81.22 & 79.5 & 1.72 & 1.12 & 11.94 & 6.54 & 4.53 & 40 \\
\hline 3 & 81.34 & 78.0 & 3.34 & 1.35 & 15.40 & 5.73 & 3.74 & 40 \\
\hline 4 & 75.92 & 72.5 & 3.42 & 0.87 & 31.57 & 6.46 & 4.02 & 33 \\
\hline 5 & 79.58 & 76.2 & 3.38 & 1.56 & 28.49 & 6.31 & 3.08 & 36 \\
\hline 6 & 85.07 & 82.7 & 2.37 & 1.07 & 37.62 & 6.42 & $<1$ & 48 \\
\hline 7 & 76.98 & 75.0 & 1.98 & 0.82 & 36.69 & 6.44 & 2.15 & 36 \\
\hline 8 & 78.91 & 76.0 & 2.91 & 0.80 & 38.23 & 6.41 & 2.39 & 36 \\
\hline 9 & 83.06 & 80.5 & 2.56 & 1.02 & 25.63 & 6.50 & 4.32 & 35 \\
\hline 10 & 83.03 & 78.5 & 4.53 & 1.01 & 22.00 & 6.53 & 4.27 & 38 \\
\hline 11 & 77.57 & 76.7 & 0.87 & 1.12 & 30.69 & 6.46 & $<1$ & 40 \\
\hline 12 & 77.35 & 74.2 & 3.15 & 0.89 & 39.60 & 6.50 & $<1$ & 40 \\
\hline 13 & 87.51 & 81.2 & 6.31 & 0.82 & 37.95 & 5.60 & $<1$ & 45 \\
\hline 14 & 86.88 & 83.2 & 3.68 & 1.01 & 37.62 & 7.08 & 4.78 & 39 \\
\hline 15 & 85.41 & 83.2 & 2.21 & 1.02 & 33.55 & 6.45 & 3.18 & 40 \\
\hline 16 & 87.61 & 80.2 & 7.41 & 0.95 & 21.23 & 6.53 & 3.43 & 42 \\
\hline 17 & 83.61 & 79.5 & 4.11 & 0.92 & 41.47 & 5.97 & $<1$ & 40 \\
\hline 18 & 81.84 & 79.2 & 2.64 & 1.00 & 26.40 & 6.76 & $<1$ & 39.5 \\
\hline 19 & 82.64 & 81.7 & 0.94 & 0.90 & 38.06 & 6.93 & 3.69 & 38 \\
\hline 20 & 80.10 & 77.5 & 2.60 & 1.27 & 47.30 & 6.87 & $<1$ & - \\
\hline 21 & 85.43 & 83.2 & 2.23 & 1.20 & 44.55 & 7.84 & 5.09 & 40 \\
\hline 22 & 81.61 & 79.5 & 2.11 & 1.09 & 28.60 & 6.63 & $<1$ & 40 \\
\hline 23 & 82.62 & 81.2 & 1.42 & 1.04 & 28.27 & 6.50 & $<1$ & 38 \\
\hline 24 & 78.06 & 76.0 & 2.06 & 1.41 & 19.36 & 7.73 & $<1$ & 40 \\
\hline 25 & 90.86 & 83.2 & 7.66 & 1.35 & 6.33 & 7.41 & 4.44 & 35 \\
\hline 26 & 87.24 & 86.0 & 1.24 & 1.74 & 7.59 & 6.82 & $<1$ & 33 \\
\hline 27 & 88.46 & 83.0 & 5.46 & 1.42 & 4.62 & 6.98 & 4.32 & 25 \\
\hline 28 & 77.32 & 75.8 & 1.52 & 1.29 & 22.44 & 6.59 & 2.23 & 46 \\
\hline 29 & 81.04 & 78.8 & 2.24 & 1.11 & 26.07 & 6.87 & $<1$ & 44 \\
\hline 30 & 83.12 & 80.2 & 2.92 & 0.99 & 28.22 & 6.89 & 3.29 & 45 \\
\hline 31 & 85.34 & 83.5 & 1.84 & 1.51 & 27.34 & 8.04 & 3.45 & 45 \\
\hline 32 & 82.11 & 79.2 & 2.92 & 1.10 & 27.17 & 7.72 & $<1$ & 38 \\
\hline 33 & 82.09 & 79.0 & 3.09 & 1.13 & 28.16 & 7.12 & $<1$ & 49.5 \\
\hline 34 & 86.24 & 82.2 & 4.04 & 1.33 & 24.31 & 6.21 & 2.21 & 47.5 \\
\hline En düşük/Min & 75.92 & 72.5 & 0.87 & 0.80 & 4.35 & 5.60 & $<1$ & 25 \\
\hline En yüksek/Max & 90.86 & 86.0 & 7.66 & 1.74 & 47.30 & 8.04 & 5.09 & 49.5 \\
\hline
\end{tabular}


TS 1331 (Anonymous, 2015) “tereyağ1 süt ve/veya süt ürünlerinin tekniğine uygun olarak işlenmesi sonucunda elde edilen, gerektiğinde mevzuatına uygun katkı maddeleri, çeşni maddeleri ve diğer katkı maddeleri de katılabilen süt mamulü" olarak tanımlanmaktadır. Altı tipe ayrılmış tereyağlarının hiçbirinde bitkisel yağ bulunmamalı hükmü yer almakta ve yağ oranlarına göre tereyağları isimler almaktadır. Buna göre incelenen 34 adet tereyağ adedinde yağ oranı \%80.2 ile \%86 arasında bulunmuş olup $\% 80$ ile $\% 90$ yağ içeren tip olan "tam yağlı tereyağı" tipine girmektedir. İncelenen diğer 18 adet tereyağı örneğinde ise \%72.5 ile \%79.5 yağ oranı ile Tereyağı Standardında sadece süt yağ içeren (çeşnisiz) tiplerden herhangi birine girmemektedir (yağı azaltılmış tereyağı: \%60-62 süt yağlı ve yarım yağlı tereyağı: \%39-41 süt yağlı) (TS 1331). Standartta, çeşnili tereyağlanı olarak 2 farklı tip ismi verilen ve çeşni maddelerinin (baharat, meyve ve sebzeler, bal ve/veya diğer gıda maddeleri) bir veya birkaçının katılması ile elde edilen tereyağlarında da yăg oranları çok farklıdır (çeşnili tam yağlı: $\geq 75$ süt yağı içeren ve çeşnili yağ1 azaltılmış: \%62-75 süt yağ1 içeren). Standartta dipnot olarak verilen "Süt yağ1 oran1 Çizelgede verilen değer aralıkları dışında olması halinde tereyağı en yakın alt tipe dahil edilir" ifadesi kafaları çok karıştırmaktadır. En yakın alt tip “yağ1 azaltılmış tereyağı" (\%60-62 süt yağlı) mi? yoksa en yakın tip mi (tam yağlı tereyağı, \%8090 süt yağlı) tam olarak anlaşılamamaktadır. Bu araşurmada 18 adet örnekte belirlenen yağ oranlanı tam yağlı tipe girmediği halde ya tam yağlı olarak veya yarım yağlı olarak değerlendirilecek demektir. $\mathrm{Bu}$ durum, dürüst üretim yapan üreticilerin maddi olarak çok zarar görmesine ve tüketicilerin de daha fazla süt yağ içeren tereyağına göre yetersiz beslenmesine, aldatilmasina ve fazla para ödemesine neden olacaktır. Ayrıca kitlede eksik süt yağı olması demek, diğer hilelerin yapılmasına kapı aralayacak, margarin gibi diğer yağların katılma şüphesini kuvvetli hale getirecek ve kontrolü zorlaştıracaktır. Bu bakımdan başta Erzurum'daki süt sanayicileri olmak üzere, işini düzgün yapan süt sanayicilerimizin yakarışlarının, sadece yağ oranları bakımından bile, ne kadar haklı olduğunu ortaya çıkarmıştır. $\mathrm{Bu}$ nedenle tereyağının "tereyağı" olarak adlandırılması ve süt yağı oraninin en az \%80 olmasinda fayda olduğu; haksız rekabet ve tüketici sağlığ1 ve aldatılmaması bakımından çok önemlidir. Resmi kontrollerde, Tereyağ1 Standardından 10 yıl önce çıkarlan “Türk Gıda Kodeksi Tereyağı, Diğer Süt Yağ1 Esaslı Sürülebilir Ürünler ve Sadeyağ Tebliğinin (Anonymous, 2005) dikkate alındığ1 göz önünde bulundurulduğunda da; Tebliğde süt yağ1 esaslı sürülebilir ürün "Sadece süt ve/veya süt ürünlerinden elde edilen, ana bileşeni yağ olan, temel olarak yağ içinde su emülsiyonu tipinde, şekillendirilebilir, $20^{\circ} \mathrm{C}$ sıcaklıkta katı yapıda olan ürünü" kastetmektedir. Süt yağı esaslı sürülebilir ürünler de piyasaya sunuluş ve bileşimlerine göre sinıflandirilmakta ve bu siniflandırmada “Tereyağ1, ağırllkça en az \%80, en fazla \%90 oranında süt yağı, en fazla $\% 2$ oranında yağsız süt kuru maddesi ve en fazla \%16 oranında su içeriğine sahip ürün" olarak tarif edilmektedir. Buna göre, bu araşturmada incelenen yağların, Tereyağ1 Standard1 (Anonymous, 2015)'nda olduğu gibi \%47'si (16 adet) “tereyağı" sınıfina girmektedir (Çizelge 1). Yine 22 adet örnekte su oranı \%16'dan fazla olduğu için Tebliğe (Anonymous, 2005) uymamaktadır (Çizelge 1). Tebliğ (Anonymous, 2005)'e göre incelenen yağlar içinde "Dörtte üç yağlı tereyağı" (ağırllkça $\leq \% 60$ ve $\geq \% 62$ süt yağı içeren), "Yarım yağlı tereyağı" ( $\leq \% 39$ ve $\geq \% 41$ süt yağ1 içeren) sinıfina giren yağ bulunmamaktadır. Ancak, 18 adet örnek \% >62 ile $<80$ yağ içeriği ile "süt yağı esaslı sürülebilir ürün” sınıfına girmektedir. Aynı Tebliğ, anlaşılması zor ve karmaşı ifadeleri de kapsamaktadır. Örneğin, süt yağı içeriği $\% 41$ den fazla, \%62 den düşük olan ürünlerde "yağ1 azaltılmış" ifadesi, süt yağı içeriği $\% 41$ veya daha düşük olan ürünlerde "düşük yağlı" veya "az yağlı" veya benzeri ifadeler, yer alabilir denilmektedir. Ancak bu ifadeler aynı Tebliğin Eki olan Çizelgedeki (EK 1) oranları tam olarak tutmamaktadır. Bu araştırmada alınan numuneler zaten tek bir isimle ve "tereyağı" olarak satıldığ için Tebliğ'de geçen diğer sinıflandırmalara göre yăg örneği yoktur. Tebliğ'de de sütyağ1 sinırları belirtilmiş, ancak Standartta olduğu gibi başka yağların da olabileceği "Ürün Özellikleri” (Madde 5, g) bölümünde "Ürünlerde tuz hariç kuru maddede süt yağı en az 2/3 oranında olmalıdır" 
(Anonymous, 2005) ifadesinden anlaşılmaktadır. $\mathrm{Bu}$ bakımdan incelenen 34 adet yağın 33 adedi tereyağ1 olarak satıldığına göre (1 adet örnek bitkisel katkılı tereyağ1 olarak satıldığından), bunlardan sadece 16 adedi gerçek tereyağı olarak değerlendirilebilir.

Konuyla ilgili olarak tereyağ1 örneklerinin kilogram fiyatları da 25 ile 49.5 Türk Liras1 arasında geniş bir aralıkta değişmiştir (Çizelge 1). Örneklerden sadece 1 adedinin bitkisel katkilı olduğu belirtilerek 25 TL fiyatla satıldığ görülmüştür. Halbuki Tereyağı Standardı (Anonymous, 2015)'nda bitkisel yağ bulunmamalı hükmü bulunmaktadır. Ne yazıkki bu örneğin yăg oranı \%83 olarak tespit edilmiş ve tam yağlı tereyağ1 tipine girmektedir. Bu durum da, tereyağ 1 olarak satılan yağların, yağ oranlarının süt yağı olarak hilesiz olduğunu belirlemede tam bir çözüm olmayacağını ortaya koymaktadır. Bu nedenle her ne kadar yeni Tereyağ1 Standard1 (Anonymous, 2015) ve Tebliğ (Anonymous, 2005)'de olmasa da tereyağına diğer yağların katılıp katılmadığını belirlemede R.M. sayısı, halen geçerliliği olan, hızlı ve ucuz bir yöntemdir (Pradhan, 2016; Altun vd., 2017). Örneğin katk1 oranı fazlalaştıkça güvenilirliği de artmaktadır (Pradhan, 2016; Tahmas Kahyaoğlu ve Çakmakç1, 2016). Bu nedenlerle de tereyağında R.M. sayısının da belirlenerek daha emin olunması yarar sağlayacaktır. Yağlarda R.M. sayısı su buhant ile uçan, suda eriyen bütirik, kaproik, kaprilik ve az miktarda kaprik asitleri gösterir. Süt yağının R.M. sayısının ortalama 27 olduğu ve 23-33 arasinda değiştiği (Metin ve Öztürk, 2002), inek yağlarında 19-34 arasında değiştiği ve iç, kuyruk ve böbrek yağlanı ile katkılı yağlarda genellikle 24' ün altında bulunduğu belirtilmektedir (Kurt vd., 2012). Bu araşturmada, incelenen yağlarda belirlenen R.M. sayıları Çizelge 1'de verilmiştir. Örneklerin R.M. say1lar1 4.35 ile 47.30 olarak geniş bir aralıkta değişmiştir. Pradhan (2016) ise standart (kontrol) tereyağında ortalama R.M. sayısının 27.65 olduğunu tespit etmiştir. Hayaloğlu (1999) tarafindan Malatya piyasasından toplanan hem yoğurt tereyağlarında tespit edilen en düşük (20.84) ve en yüksek (28.98) R.M. saylları hem de krema tereyağlarında 23.70 ve 28.30 arasında değişen değerler ile yine aynı çalışmada laboratuvarda üretilen yoğurt ve krema tereyağlarında tespit edilen R.M. sayıları (25.64 ve 29.93 arası) göz önünde bulundurulduğunda, saf süt yağından yapılan tereyağlarının R.M. sayılarının 20-30 arasında değişebileceği anlaşılmaktadır. $\mathrm{Bu}$ literatür bilgileri ile karşılaşturıldığında Erzurum'da satşsa sunulan yağların çoğunun hileli olduğu ortaya çıkmaktadır. Tahmas Kahyaoğlu ve Çakmakçı (2018) da inek, koyun ve keçi sütünden üretip 90 gün süresince buzdolabında muhafaza ettikleri tereyağ örneklerinde 15 'er günlük periyotlarda belirlenen en düşük ve en yüksek R.M. sayılarını sırasıyla 25.21-25.83; 26.50-26.87 ve 26.08-26.42 olarak bulmuşlardır. Yine Tahmas Kahyaoğlu ve Çakmakçı (2016) tarafindan tereyağına kontrollü oranlarda margarin katılarak matematiksel bir formül geliştirilmesine yönelik yapılan araştırmada, saf inek sütü kremasından yapilan kontrol tereyağının R.M. sayıs1 26.17 olarak bulunmuştur. Buna karşlik margarin fabrikasından alınan saf margarin ve pastacllikta kullanilan margarinlerin R.M. sayilar1 sirasiyla 12.80 ve 13.61 olarak saptanmıştır (Tahmas Kahyaoğlu ve Çakmakç1, 2016). Bu araştırma sonuçlarından da görüldüğü gibi margarinlerin R.M. sayısı tereyağlarından çok düşüktür. Kontrol örneklerinin sonuçlarını veren literatür bilgileri, bu araştırmada incelenen yağların 6 adedine kesin olarak ve yüksek oranda başka yağların karıştırıldığını gösterirken (R.M. aralıkları: 4.3515.40), 6 adedinin yine aynı şekilde şüpheli olduğunu (R.M. aralıklar1: 38.06-47.30) ve toplamda 12 adet örneğin katk1lı olduğu söylenebilir. Ancak inek tereyağında en yüksek R.M. sayısı (34) ile karşılaştırıldığında (Kurt vd., 2012) 10 adet örneğe ne karıştırildığı bu teknikle anlaşılmayacak kadar şüpheli olduğunu göstermektedir (R.M. sayl aralığ1: 36.69-47.30) (Çizelge 1). Daha önce Erzurum sütlerinden kontrol olarak üretilen ve hilesiz olduğu kesin bilinen tereyağı araşturma sonuçlarından R.M. sayısının genellikle 24-28 aralığında olduğu sonucundan (Pradhan, 2016; Tahmas Kahyaoğlu ve Çakmakçı, 2016, 2018), bu araştırmada incelenen 34 örnekten yalnız 6 adedinin bu sinır içinde olduğu, yakın değerler de sayıldığında (5 adet) toplam 11 adedinin (\%32.4) sadece süt yağ1 içerdiği söylenebilir. 
Tereyağ1 Standardı (Anonymous, 2015) ve Tebliğ (Anonymous, 2005)'de, tereyağlarda yağsız kurumadde oranı ağırlık olarak en fazla $\% 2$ olarak sınırlandırılmıştır. Tereyağında aroma maddesi olan diasetil, yıkamanın sayısına ve yoğunluğuna bağlı olarak \%30-50 oranında yağdan uzaklaşmakta ve tereyağı aroması azalmaktadır (Atamer ve Şenel, 2014). Bu nedenle tereyağının az y1kanmasi durumunda protein oranı artmakta ancak toplam yağsız kurumadde sinırı \%2'yi geçmemelidir. $\mathrm{Bu}$ araşturmada ise incelenen örneklerde yağsız kurumadde oranları $\% 0.87$ ile \%7.66 arasında değişmiş, 26 adet örnekte \%2'den yüksek değer tespit edilmiş (\%76.5) ve mevzuata uygun bulunmamıştır (Çizelge 1). Özellikle 8 örnekte en yüksek değerin izin sınırının 2 katından daha yüksek, 5 örnekte 2.5 katından daha yüksek yağsız kurumadde bulunması (Çizelge 1), üretim sırasında bu tereyağların iyi yıkanmaması nedeniyle protein oranının yüksekliği dışında, yağ dışında olabilecek diğer hileleri akla getirmektedir.

Yağların bir başka kalite özelliği taze olması/uygun şartlarda korunup korunmadığıdır. Yağ ve yağlı gidalarda raf ömrünü sınırlayan en önemli faktör oksidasyondur. Oksidasyonun derecesine göre yağın renk, lezzet ve besleyici değeri zarar görmekte, tüketim tercihi etkilenmekte ve raf ömrü azalmaktadır. Daha da önemlisi ileri derecede okside olmuş yağların sağllğa olumsuz etkileri olduğuna dair çok sayıda makale yayınlanmıştır (Kanner, 2007; Asha vd., 2015; Vieira vd., 2017). Oksidasyon üzerine yağın depolama sıcaklığı, süresi ve ambalaj önemli etkili faktörler olarak sayllabilir (Öztürk ve Çakmakçı, 2006; Asha vd., 2015). Nitekim Tebliğde "satış noktalarındaki muhafaza sicakllğ $4{ }^{\circ} \mathrm{C}$ ' den yüksek olmamalıdır" hükmüne rağmen, örneklerden yığın olarak satılanların çoğunun satış yerinin normal sicaklığında olduğu görülmüştür $\left(>4^{\circ} \mathrm{C}\right)$. Peroksit sayısı yağlarda primer oksidasyon ürünlerinin derecesini gösteren bir indikatördür ve oksidasyon seviyesini belirlemede kullanilır (Anwar vd., 2007; Asha vd., 2015). Bu araştırmada, incelenen yağların peroksit saylları 0.80 ile 1.74 meq $\mathrm{O}_{2} / \mathrm{kg}$ arasında değişmiştir. $\mathrm{Bu}$ sonuçlar, Malatya piyasasında satılan yoğurt tereyağlarındaki peroksit sayılanı (0.50-5.0 meq $\mathrm{O}_{2} / \mathrm{kg}$ ) ile krema tereyağlarında saptanan değerlere (1.0-7.0 meq $\mathrm{O}_{2} / \mathrm{kg}$ ), örneğe bağlı olarak benzer ve/veya farklı olduğu görülmüştür. Laboratuvarda üretilen her iki tereyağında da peroksit sayısinin 0.0 meq $\mathrm{O}_{2} / \mathrm{kg}$ olarak bulunması (Hayaloğlu, 1999), kontrollü üretim ve depolamanın önemini göstermesi bakımından önemlidir. Yokuş vd. (2019) de Şanlıurfa'dan aldıklar1 15'er adet koyun ve inek Şanlıurfa Sadeyağ1 örneğinin peroksit sayılarını sırasılya, $0.122-0.338$ meq $\mathrm{O}_{2} / \mathrm{kg}$ yağ arasında ve 0.012 $0.385 \mathrm{meq} \mathrm{O}_{2} / \mathrm{kg}$ yağ arasında bulmuşlardır. $\mathrm{Bu}$ sonuçlar, yapılan bu araştırma bulgularından çok düşük olup, üretimde uygulanan işlemlerin etkisi, süt çeşidi ve diğer bazı faktörlerin etkili olduğu anlaşılmaktadır. Bu araştırmada bulunan değerler, Tahmas Kahyaoğlu ve Çakmakçı (2018) tarafindan koyun, keçi ve koyun kontrol tereyağlarının 90 günlük periyotta tespit edilen en düşük (tespit edilememiş) ve en yüksek ( $0.55 \mathrm{meq}$ $\mathrm{O}_{2} / \mathrm{kg}$ ) peroksit sayılarından da çok yüksek olarak tespit edilmiştir. Araştırmada bulunan en düşük değer (0.80 meq $\mathrm{O}_{2} / \mathrm{kg}$ ) (Çizelge 1), Öztürk ve Çakmakçı (2006)'nın $4{ }^{\circ} \mathrm{C}$ 'de 6 ay süresince depolayıp her ay inceledikleri kontrol tereyağlarda tespit edilen ortalama değere (0.78) benzer bulunmuştur. Dağdemir vd. (2009) de, 90 gün 4 ${ }^{\circ} \mathrm{C}$ 'de ve Gündoğdu (2012) da, $4{ }^{\circ} \mathrm{C}$ 'de 60 gün depoladıkları kontrol inek sütü tereyağlarında depolama süresince daha düşük peroksit sayıları tespit etmişlerdir. Benzer şekilde Bakırc1 vd. (2002) de çeşitli kültürlerle üretip 4 ve $-18{ }^{\circ} \mathrm{C}$ 'de depoladıkları tüm tereyağı örneklerinin ilk 60 gündeki peroksit sayılarını bu araştırma sonuçlarından daha düşük bulmuşlardır. Araşturmada bulunan en yüksek değer (Çizelge 1), Şenel vd. (2011)'nin inek ve koyun yoğurdundan yaptıkları tereyağlarında 30 günlük depolama süresinde tespit ettikleri ortalama peroksit sayılarından (sirasiyla 0.50 ve $1.10 \mathrm{meq} \mathrm{O}_{2} / \mathrm{kg}$ ) yüksek bulunurken, keçi yoğurdundan düşük bulunmuştur. Yürürlükteki Tereyağ1 Standardı (Anonymous, 2015)'nda peroksit sayıs ile ilgili bir hüküm bulunmadığ1 için bir karşılaştırma yapılamamıştur. Ancak, daha önce yapılan ve kontrol örneklerin peroksit sayılarının araştırıldığ1 araştırma sonuçlarının tüm değerleri göz önüne alındığında; bu araştırmada çoğu örnekte bulunan peroksit sayılarının çok yüksek olduğu söylenebilir (Çizelge 1). İncelenen örneklerden 25 adedinin 
1.0'dan fazla, 16 örneğin 1.1'den, 11 örneğin 1.2 'den, 8 örneğin 1.3 'den, 5 örneğin 1.4 'den, 2 örneğin 1.5'den ve 1 örneğin de $1.7 \mathrm{meq} \mathrm{O}_{2} /$ kg'dan fazla peroksit sayısı bulunmuştur (Çizelge 1). Daha önce yapılan araştırmalarda inek, koyun ve keçi sütü kaynaklı ve buzdolabında farklı sürelerde (6 ay dahil) depolanan kontrol tereyağlarında bile $1.1 \mathrm{meq} \mathrm{O}_{2} / \mathrm{kg}^{\prime}$ dan büyük peroksit sayısı bulunmadığı göz önüne alındığında, 16 örneğin peroksit sayısının yüksek olduğu ve peroksit sayısının 1'den fazla olduğu örneklerde duyusal olarak da ransit tat hissedildiği belirlenmiştir. Bu sonuçlar, tereyağı örneklerinin çoğunun taze olmadığını, uygun sicaklıkta depolanmadığını, açıkta veya az bir kısmının da 1şık geçiren streç film benzeri ambalaja sarllarak pazarlandığından kaynaklanmış olabilir.

Erzurum piyasasından alınan örneklerde tespit edilen koliform bakteri ve maya ve küf sayllar1 Çizelge 1'de görülmektedir. Tereyağlarında bulunması istenmeyen bu mikroorganizmaların geniş bir aralıkta değiştiği ve nispeten sevindirici bir sonuç olarak 14 adet örnekte (\%41.2) koliform bakteri tespit edilmezken $(<1 \log \mathrm{KOB} / \mathrm{g})$, ne yazkkki $5.09 \log \mathrm{KOB} / \mathrm{g}$ seviyesinde olan örnek de bulunmaktadır. Tereyağı örneklerinde önemli bir sorun da küf gelişimidir. Her ne kadar Tereyağ 1 Standard1 (Anonymous, 2015)'nda ve Tebliğ (Anonymous, 2005)'de büyük bir eksiklik olarak, bu konuda bir hüküm bulunmasa da araştırmalar ve Türk Gıda Kodeksi Mikrobiyolojik Kriterler Yönetmeliği (Anonymous, 2011)'nde tereyağ1 olmasa da diğer yağlar için en fazla $10^{2}$ $\mathrm{KOB} / \mathrm{g}^{\prime} d a n$ fazla olmaması belirtilmiştir. Örneklerde 5.60 ile $8.04 \log \mathrm{KOB} / \mathrm{g}$ arasında maya ve küf tespit edilmiş olup hiçbir örnek bu bakımdan kabul edilebilir sınırlarda değildir. Tereyağ1 örneklerinin $1 / 3$ ' ünün satşs noktasındaki ortam sıcakllğında yığın şeklinde, diğer kısmın da ticari buzdolabında satışa sunulduğu gözlenmiştir. Özellikle açık olarak satılan örneklerde ambalaj olmadığı için üretim zamanı ve üretim yerinden satış noktasına hangi şartlarda getirildiğinin bilinmediği gözlenmiştir. $\mathrm{Bu}$ nedenlere bağlı olarak maya ve küf sayısının yüksek olduğu söylenebilir.
Renk, tereyağının önemli kalite/güvenilirlik özelliklerinden biri olup elde edildiği hayvan türü ve beslenmeye bağlı olarak hafif değişiklik gösterebilmektedir. Koyun ve keçi sütlerinden yapılan tereyağlarında sadece A vitamini olduğundan beyaz, inek sütü tereyağlarında ise hem A vitamini hem de $\beta$-karoten olduğundan krem rengimsi, hafif sarımsı olmaktadır (Tahmas Kahyaoğlu ve Çakmakçı, 2018). İncelenen yağ örneklerine ait renk parametreleri $\left(L^{*}, a^{*}, b^{*}, H^{\circ}\right.$ ve $\left.C^{*}\right)$ Çizelge 2'de verilmiştir. Rengin açıklık ve koyuluk özelliklerini ifade eden $L^{*}$ değeri, renk açıldıkça 100'e yaklaşmaktadır (parlaklık; 0: siyah, 100: beyaz). Araştırmada elde edilen $L^{*}$ değeri 79.76-86.51 aralığında değişim göstermiştir. Bu durum, Şekil 1'de verilen yă̆ örneklerine ait fotoğrafların incelenmesiyle de görülmektedir.

En düşük ve en yüksek $a^{*}$ değerleri sirasıyla -5.21 (6 numaralı örnek) ve -2.15 (22 numaralı örnek) arasında bulunmuştur. $a^{*}$ değerinin pozitif $(+)$ olması kırmız1, negatif (-) olması yeşil olduğuna göre; ölçülen $a^{*}$ değerlerinin tüm örneklerde “_" olması, rengin açık olduğunu göstermektedir. Örneklerin $b^{*}$ değerleri ise 13.80 ile 42.18 aralı̆̆ında değişim göstermiştir. $b^{*}$ değerinin pozitif $(+)$ olmas1 san, negatif (-) olmas1 mavi olduğuna göre; sar1, sarıms1, $L^{*}$ değerlerini de dikkate alarak beyaz, beyaza yakın olduğunu göstermektedir. İncelenen tüm yağ örneklerinin $H^{\circ}$ değerleri (93.7-100.6) beyaz-sarı bölgedeki bir renk tonunu temsil etmektedir. Rengin doygunluk derecesini, saflığını veya yoğunluğunu ifade eden $C^{*}$ değeri ise 13.96-42.31 aralığında değişim göstermiştir. Tahmas Kahyaoğlu ve Çakmakçı (2018) inek, koyun ve keçi tereyağlarında ortalama $L^{*}$ değerlerini, sirasiyla 84.63;83.53;84.50, $a^{*}$ değerlerini $-3.80,-3.77$ ve $-3.76, b^{*}$ değerlerini de $19.21,10.90$ ve 8.35 tespit etmişlerdir. Ayrıca taze tereyağ1 ile 90 günlük depolama süresi arasında renk değerlerinde değişim olmakla birlikte değerler türler içinde benzer değerler arasındadır. Buna göre, bu araştırmada ölçülen değerler inek tereyağı değerleri ile karşılaştırıldığında; 12 adet örneğin doğal/saf olarak inek sütü tereyağı olarak değerlendirilebileceği söylenebilir. Çizelge 1 ve Şekil 1 'in birlikte incelenmesinden de görüleceği gibi, baz1 örneklere fazla miktarda renk maddesi/boya katıldığı ve çoğu örneğin de tam 
beyaza yakın olması; aynı mevsimde, aynı yörede satılan ve inek sütü tereyağ1 olarak değerlendirilmesi durumunda, çok sarı olanlara boya katıldığını, beyaz olanların da (bu araşturmanın bazı analizleri için gerekli olan eritme basamakları sirasinda da hissedilen margarin veya yabancı kokudan anlaşıldığı gibi), margarin ve başka yağ ve/veya katkıların katıldığını göstermektedir. Tereyağına renk maddesi katılmasına neden olarak, toplumda oluşmuş olan "sarı renkli yağların hakiki tereyağı olarak algılanması" gibi yanlış bir yargı yatmaktadır. Bu alg1 hiç de gerekli olmayan bir katkının kullanılmasına yol açmıştr. Halbuki bu durum ancak laboratuvarda analizle anlaşılır. İnek sütü tereyağı, yukarıda da bahsedildiği gibi hem renksiz olan A vitamini ve sarı renkli $\beta$-karoten varllğ1 nedeniyle beslemeye de bağlı olarak sarı, sarımsı, kremsi renklerde olmaktadır. Ancak bu araştırmada özellikle 26 ve 33 numaralı örnekler başta olmak üzere $5,9,25,26$ ve 33 numaralı örneklere normalin üzerinde boya katıldığ1 görülmektedir. Bu örneklerden 4'ünün açık yığın olarak, 1 örneğin de şeffaf streç film benzeri bir malzeme ile ambalajlanmış olması ve etiketinde bu konuda bir bilgi olmadığ göz önünde bulundurulduğunda, kontrolün ne kadar zor olacağı ortaya çıkmaktadır. Bunun yerine tüketici, tereyağının rengi konusunda bilimsel eğitim programlanı ile bilgilendirilmeli ve tereyağına renk maddesi katılmamalıdır.

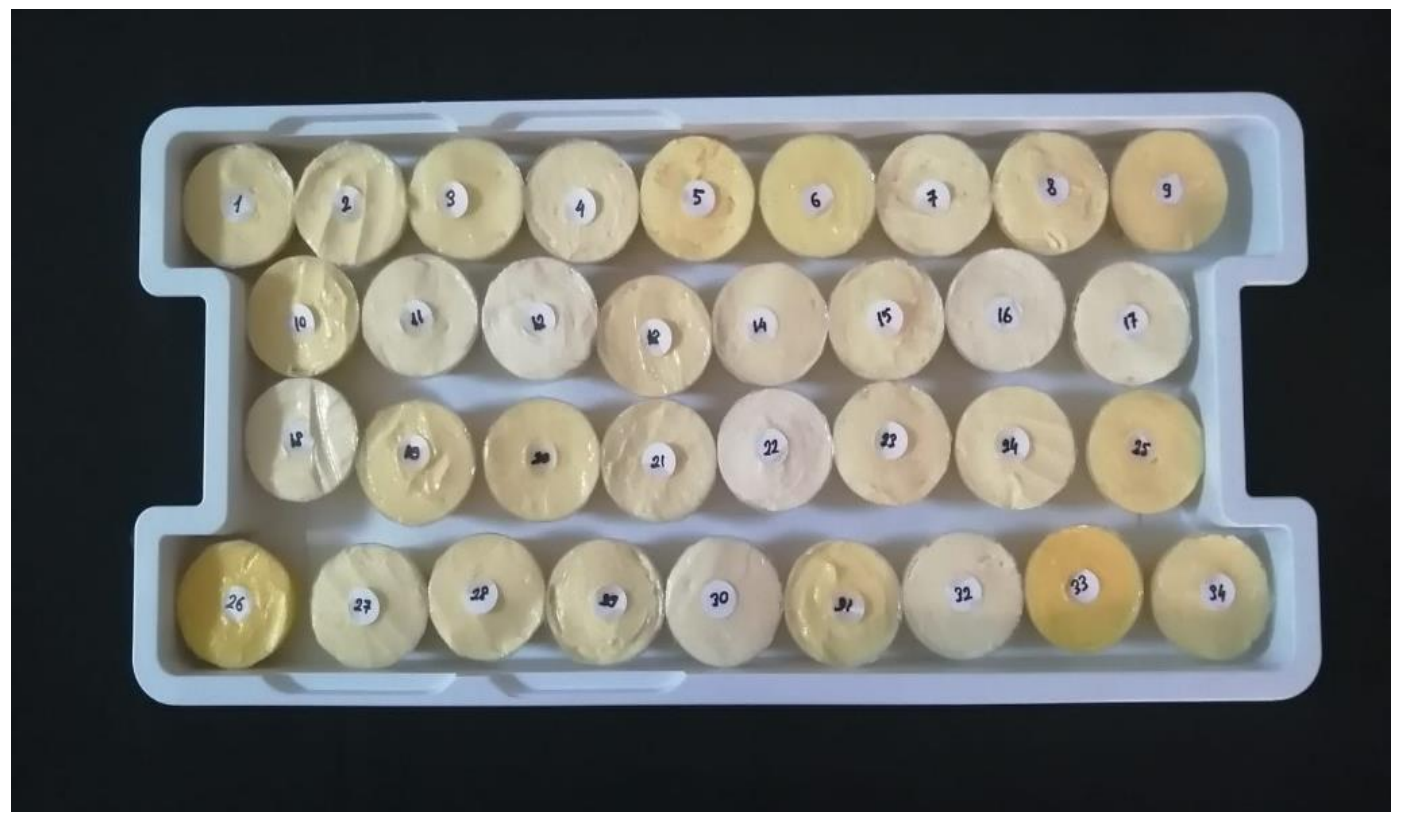

Şekil 1. Yağ örneklerinin renk ve görünüş fotoğrafları

Figure 1. Color and appearance photos of fat samples

Tüketicilerin/okuyucuların meraklarını gidermek için, bu araştırmada incelenen tereyağların renk ve görünüşlerini yansıtan fotoğrafları Şekil 1 ve örnekler arasındaki renk farklılığ Şekil 2'de verilmiştir. Fotoğraflardan da görüleceği gibi 26 ve 33 numaralı örnekler başta olmak üzere 5, 6, 9, 25,26 ve 33 numaralı yağ örneklerinin çok sarı olduğu panelistlerce de belirtilmiştir. Ayrıca 11, $12,16,17,18,22,30$ ve 32 numaralı örneklerin de tereyağında olmayacak margarinimsi, ransit tat ve kokuda ve tam beyaz olduğu belirtilmiştir. $\mathrm{Bu}$ sonuçlar da tereyağı olarak satışa sunulan yağlarla ilgili sorunlar olduğunu göstermektedir. Her ne kadar Tebliğ ve Standartta süt yağı oranlan farklı yağlar, farklı isimlerle ifade edilse de ve çeşnili tereyağ1 çeşitleri olsa da, bu araştırmada olduğu gibi çoğunun ambalajsı olması, sarılan ve etiket yapıştırılanlarda da eksik bilgiler olması, bu yağların çoğunun hileli olduğunu göstermektedir. Çünkü 1 adet örnek hariç, 33 adet örnek tüketiciye "tereyağı" olarak sunulmakta ve fiyatları da tereyağı olanlara benzer fiyatlarla satılmaktadır. 
Çizelge 2. Tereyağı olarak satılan yağların renk değerleri Table 2. Color values of fats sold as butter

\begin{tabular}{|c|c|c|c|c|c|}
\hline $\begin{array}{c}\text { Örnekler } \\
\text { Samples }\end{array}$ & $L^{*}$ & $a^{*}$ & $b^{*}$ & $C^{*}$ & $H^{\circ}$ \\
\hline 1 & 84.20 & -3.25 & +26.89 & 27.08 & 96.8 \\
\hline 2 & 84.28 & -3.01 & +25.05 & 25.22 & 96.8 \\
\hline 3 & 84.05 & -4.00 & +24.86 & 25.17 & 99.1 \\
\hline 4 & 86.29 & -2.31 & +21.92 & 22.04 & 96.0 \\
\hline 5 & 84.15 & -2.58 & +31.20 & 31.30 & 94.7 \\
\hline 6 & 82.91 & -5.21 & +27.80 & 28.28 & 100.6 \\
\hline 7 & 86.06 & -2.64 & +22.09 & 22.24 & 96.8 \\
\hline 8 & 86.51 & -2.51 & +23.75 & 23.88 & 96.0 \\
\hline 9 & 84.76 & -2.88 & +29.25 & 29.39 & 95.6 \\
\hline 10 & 84.15 & -2.98 & +28.13 & 28.28 & 96.0 \\
\hline 11 & 83.59 & -3.57 & +22.89 & 23.16 & 98.8 \\
\hline 12 & 85.63 & -3.35 & +20.34 & 20.61 & 99.3 \\
\hline 13 & 79.76 & -2.78 & +28.42 & 28.55 & 95.5 \\
\hline 14 & 82.07 & -2.91 & +18.40 & 18.62 & 98.9 \\
\hline 15 & 83.37 & -3.58 & +19.57 & 19.89 & 100.3 \\
\hline 16 & 83.32 & -2.78 & +17.15 & 17.37 & 99.2 \\
\hline 17 & 86.04 & -2.92 & +16.42 & 16.67 & 100.0 \\
\hline 18 & 84.51 & -3.43 & +20.23 & 20.51 & 99.6 \\
\hline 19 & 83.93 & -3.07 & +25.60 & 25.78 & 96.8 \\
\hline 20 & 84.21 & -3.10 & +24.66 & 24.85 & 97.1 \\
\hline 21 & 81.69 & -3.26 & +22.87 & 23.09 & 98.0 \\
\hline 22 & 86.12 & -2.15 & +13.80 & 13.96 & 98.8 \\
\hline 23 & 84.73 & -2.45 & +21.13 & 21.27 & 96.6 \\
\hline 24 & 86.32 & -2.95 & +21.94 & 22.13 & 97.6 \\
\hline 25 & 83.45 & -3.93 & +30.46 & 30.71 & 97.3 \\
\hline 26 & 79.90 & -3.37 & +42.18 & 42.31 & 94.5 \\
\hline 27 & 83.40 & -3.48 & +21.78 & 22.05 & 99.0 \\
\hline 28 & 85.83 & -2.64 & +24.01 & 24.15 & 96.2 \\
\hline 29 & 84.59 & -2.79 & +23.18 & 23.35 & 96.8 \\
\hline 30 & 84.36 & -2.53 & +17.15 & 17.33 & 98.4 \\
\hline 31 & 83.14 & -4.09 & +25.60 & 25.92 & 99.1 \\
\hline 32 & 83.71 & -2.56 & +16.82 & 17.01 & 98.6 \\
\hline 33 & 83.05 & -2.56 & +38.91 & 38.99 & 93.7 \\
\hline 34 & 83.35 & -3.62 & +26.38 & 26.62 & 97.8 \\
\hline En düşük/Min & 79.76 & -5.21 & +13.80 & 13.96 & 93.7 \\
\hline En yüksek/Max & 86.51 & -2.15 & +42.18 & 42.31 & 100.6 \\
\hline
\end{tabular}




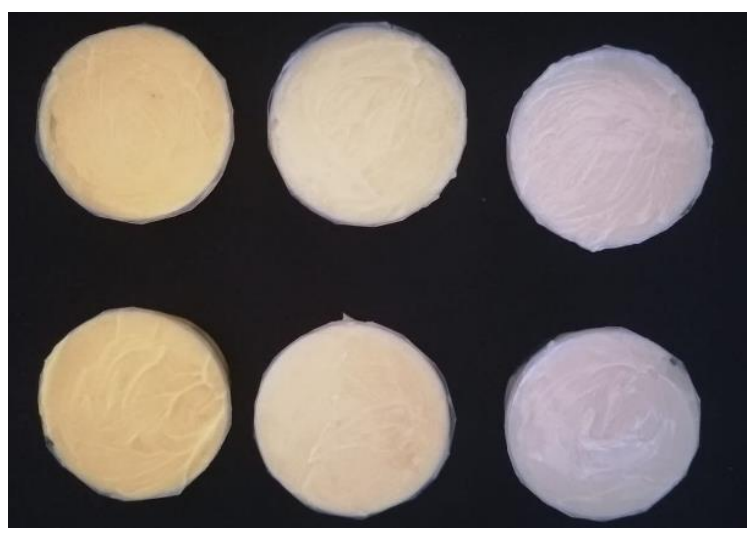

Şekil 2. Yağların renk ve görünüş farklılık aralı̆g1 Figure 2. Color and appearance difference range of fats

\section{SONUÇ}

Son yıllarda tereyağına hile yapılması yaygınlaşmış olup bu durum, haklı olarak tüketicileri ve işini düzgün yapan tereyağ1 üreticilerini ilgilendirmekte/endişelendirmektedir. Tereyağ1 hileleri tüketicinin sağllğı ve beslenmesinde risk oluşturduğu gibi yağın lezzet kalitesini düşürdüğü için gündemdeki yerini korumaktadır. Bu konudaki şüpheler nedeniyle özellikle tereyağı, en fazla hile yapilan süt ürünü şüphesini üzerinde taşımaktadır. Bu bakımdan orijinalliği garantili tereyağına talep gittikçe artmaktadır. Bunun için, tüketicilere saf süt yağ1 içeren ve sağllklı tereyağ 1 sunmak önemli bir konu olarak ele alınmalıdır. Bu araştırmada elde edilen sonuçlar, bazı hükümler bakımından yürürlükteki Tebliğ ve Standarda, bazı özellikler bakımından da bilimsel gerçekler ve pratikteki değerlendirmelere bakılarak, genel olarak değerlendirildiğinde; örneklerin çoğunun çok şüpheli olduğu (yağ, R.M. sayısı, yağsız kurumadde, renk, fiyat açısından) görülmüştür. Örneklerin tamaminda fazla sayıda maya ve küf belirlenmesi, yine çoğunda koliform bakteri bulunmas1; pastörize kremadan üretiminin ve hijyenik şartlara dikkat edilmesinin önemi ile ambalaj ve muhafaza sicakliklarının en uygun olarak sağlanmasının önemini ortaya koymuştur. $\mathrm{Bu}$ araştırma sonuçları, tereyağının üretim, muhafaza ve satış aşamalarındaki problemlerin artarak devam ettiğini, bu nedenle her aşamadaki kritik kontrol noktaları belirlenerek hijyenik şartların tam olarak sağlanması gerektiğini göstermisstir. Daha da önemlisi, yasa koyucu makamların bu konuya tam olarak eğilmeleri, standart veya tebliğ ikileme kargaşasını teke indirmeleri, Tebliğ (Anonymous, 2005) ve Standarttaki (Anonymous, 2015) belirsizlikler, olması gerekenler ve fazlalıklar düzeltilmeli, hile yapmaya açık hususlar netleştirilmelidir. Mevcut haliyle hem kontrolün zor olduğu hem de tüketici ve tüketici yanında olan işini layıkıyla yapan üreticinin korunmasının mümkün olmayacağ1 ortaya çımışır.

\section{TEŞEKKÜR}

Renk değerlerinin ölçülmesinde laboratuvar desteği veren Prof. Dr. M. Murat Karaoğlu'na teşekkür ederiz.

\section{ÇIKAR ÇATIŞMASI BEYANI}

Yazarlar, çıkar çatışması olmadığını beyan ederler.

\section{YAZAR KATKILARI}

SÇ, araştırmanın planlanması, yürütülmesi, değerlendirilmesi ve yazımını sağlamıştır. KÇ, örneklerin alınması ve analizlerin yapilmasina büyük katkı sağlamıştır. HE ve HÇ, analizlerin yapılmasına katkı sağlamışlardır. Yazarlar makalenin son halini okumuş ve onaylamışlardır.

\section{KAYNAKLAR}

Altun, S.K., Savrunlu, M., Paksoy, N. (2017). Şanliurfa ilinde üretilen sadeyağların Reichert Meissl sayllannın tespiti. Mehmet Akif Ersoy Üniv Vet Fak Derg, 2(2): 109-115. DOI: 10.24880/maeuvfd.344667

Anonymous (2005). Türk Gida Kodeksi. Tereyağı, Diğer Süt Yağı Esaslı Sürülebilir Ürünler ve Sadeyağ Tebliğ́i (Tebliğ No: 2005/19). Tarım ve Köyişleri Bakanllğı. 12 Nisan 2005 tarih ve 25784 sayllı Resmî Gazete, Ankara.

Anonymous (2011). Türk Gıda Kodeksi Mikrobiyolojik Kriterler Yönetmeliği. G1da, Tarım ve Hayvancılık Bakanlığı. 29 Aralık 2011 tarih ve 28157 (3. Mükerrer) sayllı Resmî Gazete, Ankara.

Anonymous (2015). Tereyağ (TS 1331). ICS 67.100.20; 67.200.10, Türk Standardları Enstitüsü, Necatibey Caddesi No. 112, Bakanliklar, Ankara. 
Anonymous (2019).

http://www.erzurumgazetesi.com.tr/haber/Erz urum-sut-ureticilerinden-tereyagi-tepkisi/129371 (Erişim tarihi: 08.03.2020).

Anwar, F., Siddiq, A., Iqbal, S., Asi, M.R. (2007). Stablization of sunflower oil with Moringa oleifera leaves under ambient storage. J Food Lipid, 14: 35-49. DOI:org/10.1111/ j.17454522.2006.00069.x

Asha, A., Manjunatha, M., Rekha, R.M., Surendranath, B., Heartwin, P., Rao1, J., Magdaline, E., Sinha, C. (2015). Antioxidant activities of orange peel extract in ghee (butter oil) stored at different storage temperatures. J Food S $i$ Technol, 52(12): 8220-8227. DOI: 10.1007/ s13197-015-1911-3

Atamer, M. (1993). Tereyağ Teknolojisi Uygulama Klavuzu. Ankara Üniv. Ziraat Fak. Yay. No: 1314.

Atamer, M., Şenel, E. (2014). Tereyağ Teknolojisi. Ankara Üniv. Ziraat Fak. Süt Teknol. Böl. Ankara.

Bakırc1, İ., Çelik, Ş., Özdemir, C. (2002). The effects of commercial starter culture and storage temperature on the oxidative stability and diacetyl production in butter. Int J Dairy Technol, 55(4): 177-181. DOI: $\quad 10.1046 / \mathrm{j} .1471-0307.2002$. 00056.x

Bhardwaj, S., Passi, S.J., Misra, A. (2011). Overview of trans fatty acids: Biochemistry and health effects. Diabetes Metab Syndr, 5(3): 161-164. DOI: $10.1016 /$ j.dsx.2012.03.002

Çakmakçı, S., Tahmas Kahyaoğlu, D. (2012). Yağ asitlerinin sağllk ve beslenme üzerine etkilerine genel bir bakış. Akademik Gıda, 10(1): 103-113.

Dıraman, H. (2006). Tereyağ1 ve zeytinyağında muhtemel tağşişlerin kapiler kolon gaz kromatografisi yöntemi kullanılarak cis-trans yağ asitleri düzeyi ile belirlenmesi üzerine bir çalışma. Akademik Gida, 4(23): 3-10.

Gündoğdu, E. (2012). Yoğurttan ve kremadan üretilen tereyağlanının aroma profili ve bazı kalite özellikleri üzerine kültür kullanımının ve muhafaza süresinin etkileri. Atatürk Üniversitesi, Fen Bilimleri Enstitüsü, Gıda Mühendisliği Anabilim Dalı Doktora Tezi, Erzurum, Türkiye.
Harrigan, W.F. (1998). Laboratory Methods in Food Microbiology. Academic Press, San Diego, USA. $532 \mathrm{p}$.

Hayaloğlu, A.A. (1999). Malatya yöresinde kremadan ve yoğurttan elde edilen çeşitli tereyağlarının fizikokimyasal mikrobiyolojik ve duyusal nitelikleri üzerine karşılaştırmalı bir araştırma. Çukurova Üniversitesi, Fen Bilimleri Enstitüsü, Gıda Mühendisliği Anabilim Dalı Yüksek Lisans Tezi, Adana, Türkiye.

Kanner, J. (2007). Dietary advanced lipid oxidation endproducts are risk factors to human health. Mol Nutr Food Res, 51: 1094-1101. DOI: 10.1002/mnfr.200600303

Karoui, R., De Baerdemaeker, J. (2007). A review of the analytical methods coupled with chemometric tools for the determination of the quality and identity of dairy products. Food Chem, 102: 621-640. DOI: $10.1016 / \mathrm{j}$.foodchem. 2006.05 .042

Keskin, M., Setlek, P., Demir, S. (2017). Use of color measurement systems in food science and agriculture. International Advanced Researches and Engineering Congress 2017 (IAREC' 17) Proceeding Book ISBN: 978-605-245-037-6, pp. 2350-2359.

Koca, N., Kocaoglu-Vurma, N.A., Harper, W.J., Rodriguez-Saona, L.E. (2010). Application of temperature controlled attenuated total reflectance-mid-infrared (ATR-MIR) spectroscopy for rapid estimation of butter adulteration. Food Chem. 121:778-82.

Konica Minolta, (2007). Precise color communication. Konica Minolta Photo Sensing Inc., Japan. https://www.konicaminolta.com/ instruments/knowledge/color/pdf/color_comm unication.pdf(Erişim tarihi: 10.04.2020).

Kurt, A., Çakmakç1, S., Çağlar, A. (2012). Süt ve Mamulleri Muayene ve Analiz. Metotlar Rebberi (Genişletilmiş 10. Baskı). Atatürk Üniv. Yay. No: 252/d, Ziraat Fak. Yay. No: 18, Erzurum.

Lambelet, P., Ganguli, N.C. (1983). Detection of pig and buffalo body fat in cow and buffalo ghees by differential scanning calorimetry. J Am Oil 
Chem Soc, 60: 1005-1008. DOI: org/10.1007/ BF02660216

Marikkar, J.M.N., Ghazali, H.M., Man, Y.B.C., Lai, O.M. (2002). The use of cooling and heating thermograms for monitoring of tallow, lard and chicken fat adulterations in canola oil. Food Res Int, 35: 1007-1014. DOI: org/10.1016/S09639969(02)00162-X

Metin, M., Öztürk, G.F. (2002). Süt ve Mamulleri Analiz. Yöntemleri. Ege Üniv. Ege Meslek Yüksekokulu Yay. No: 24, Bornova-İzmir.

Öztürk, S., Çakmakçı, S. (2006). The effect of antioxidants on butter in relation to storage temperature and duration. Eur J Lipid Sci Technol, 108: 951-959. DOI: 10.1002/ejlt.200600089

Pradhan, P. (2016). Effect of addition of palm oil, rapeseed oil, soyabean oil on reichert meissl value of cow milk fat. Ph.D. Dissertation, West Bengal University, Kolkata, India, 54 p.

Savaş Bahçeci, K., Acar, J. (2020). Renk analizi. http://web.hitit.edu.tr/dosyalar/duyurular/hulya cakmak@hititedutr011220189A6L8V9X.pdf (Erişim tarihi: 08.04.2020).

Şenel, E., Atamer, M., Öztekin, F.Ş. (2011). The oxidative and lipolytic stability of Yayik butter produced from different species of mammals milk (cow, sheep, goat) yoghurt. Food Chem, 127(1): 333-339. DOI: org $/ 10.1016 /$ j.foodchem. 2011.01.012

Tahmas Kahyaoğlu, D., Çakmakçı, S. (2016). Determination of adulteration of butter with margarine by using fat constants. Tarm Bilimleri Dergisi-Journal of Agricultural Sciences, 22(1): 1-8.

Tahmas Kahyaoğlu, D., Çakmakçı, S. (2018). A comparative study on some properties and oxidation stability during storage of butter produced from different animals' milk. Gida, 43(2): 283-293. DOI: 10.15237/gida.GD17081

Tan, C.P., Man, Y.B.C. (2000). Differential Scanning Calorimetric analysis of edible oils: Comparison of thermal properties and chemical composition. J Am Oil Chem Soc, 77: 143-155. DOI: org/10.1007/s11746-000-0024-6

Taşan, M., Dağlıŏlu, O. (2005). Trans yağ asitlerinin yapısı, oluşumu ve gidalarla alınması. Tekirdağ Ziraat Fak Derg, 2(1): 79-88.

Tekin, A. (2007). Margarin üretimi ve trans yağ asitleri. Bilinmeyen Yönleriyle Margarin ve Beslenmedeki Rolü (Konferans Notları, 29 Haziran,2007, İstanbul). MÜMSAD Yay. No: 1.

Vieira, S.A., Zhang, G., Decker, E.A. (2017). Biological implications of lipid oxidation products. J Am Oil Chem Soc, 94:339-351. DOI: 10.1007/s11746-017-2958-2

Yokuş, D., Karakuş, M.Ş., Atasoy, A.F. (2019). Koyun ve inek sütlerinden üretilen Şanlıurfa Sadeyağlarının fiziksel, kimyasal ve mikrobiyolojik özelliklerinin belirlenmesi. Harran Tarm ve Gida Bilimleri Derg, 23(4): 463-476. DOI: 10.29050/ harranziraat.538220 